\title{
Snow Mould Development under Conditions of Central Part of Latvia
}

\author{
Biruta Bankina* \\ Institute of Soil and Plant Sciences, LLU \\ Antons Ruza, Merabs Katamadze, Dzintra Kreita \\ Institute of Agrobiotechnology, LLU \\ Līga Paura \\ Department of Control Systems, LLU
}

\begin{abstract}
Snow mould is a common disease of winter cereals in moderate and cold climatic areas. Snow mould of winter cereals has been observed sporadically in Latvia. Sharp development of this disease (caused by Microdochium nivale) was noticed in 2005-2007. The aim of the investigations was to clarify peculiarities of snow mould development depending on different agroecological conditions. Observations of snow mould incidence were carried out in the central part of Latvia - at the Study and research farm "Peterlauki" of the Latvia University of Agriculture during 2005-2008. The average incidence of snow mould was 40\% (5-60\%) in $2005,31 \%$ (14-63\%) in 2006, and 36\% (2-95\%) in 2007. The highest incidence of the disease was established for cultivar 'Cubus' (23-95\% depending on the year and the sowing time). A moderate development of snow mould was observed for variety 'Zentos' (5-60\%), but only $2-50 \%$ of damaged plants were found for 'Tarso'. The main reason of sharp development of the disease was too early sowing of winter wheat, whereas late time of wheat sowing, on average, significantly decreased the development of snow mould $(\mathrm{p}<0.001)$. Further investigations are necessary to better understand the complex of factors which influenced wheat susceptibility against snow mould.
\end{abstract}

Key words: Microdochium nivale, hardening, sowing time, cultivars.

\section{Introduction}

Snow mould is a common disease of winter cereals in moderate and cold climatic areas (Serenius, Huusela-Veistola et al., 2005; Matsumoto, 2009). Pink snow mould severity has reached $60-70 \%$ in Russia in epidemic years (Nazarova, Korneva et al., 2008). Snow mould is caused by different fungi, but Microdochium nivale (Fries) Samuels \& Hallett (previous term Fusarium nivale, teleomorph Monographella nivalis (Schaffnit) E. Müller) and different fungi from genus Typhula are the most important in moderate climate areas.

Distribution of snow mould and conditions of overwintering are closely related. Low temperature and darkness under snow interrupt photosynthesis and reserve materials are depleted by respirations, and plants are susceptible to snow mould (Matsumoto, 2009). Development of the disease depends on the duration of snow cover and on the temperature under it.

There is no direct correlation between resistance against snow mould and frost tolerance, but, on the other hand, the more frost tolerant cultivars are also more resistant against snow mould (Gaudet, 1994).

Resistance against pink snow mould is closely related with accumulated degree-days above $0{ }^{\circ} \mathrm{C}$ from sowing. A continuous snow cover reduces resistance to pink snow mould (Nakajima, Abe, 1994). Cold hardening strongly increases the snow mould resistance. Seedlings that had been growing at an optimum temperature until the 4th leaf stage were strongly infected under conditions of artificial inoculation by $M$. nivale (Golebiowska, Wedzony, 2009).

There are different data in the literature related to resistance level of cultivars and development of snow mould. Litschko et al. have not found significant differences in resistance of cultivars, but ability of leaf regeneration has been various in their research (Litschko, Burpee et al., 1988). No specific resistance has been observed for wheat cultivars selected in Northern countries; however, a correlation has been established between resistance and cold hardening. Differences in the level of cultivar resistance could

* Corresponding author's email: 
be explained by possibility that cultivars have had cold hardening (Ergon, Tronsmo, 2006). According to findings of Sugiyma and Shimazaki, optimal conditions for hardening are temperature bellow $5{ }^{\circ} \mathrm{C}$ and an 11-hour duration of light (Sugiyma, Shimazaki, 2007).

The sowing time influences plant development in autumn, as well as plant winter hardening. Higher temperature in autumn (compared with normal) increases leaf area of plants, total biomass, and total root biomass, as well as lowers content of total sugars and conduces to weaker tolerance to frost (Hanslin, Mortensen, 2010).

Snow mould of winter cereals has been observed sporadically in Latvia. Sharp development of this disease (caused by Microdochium nivale) was noticed in 2005-2007.

The aim of these investigations is to clarify peculiarities of snow mould development depending on different agroecological conditions.

\section{Materials and Methods}

Observations of snow mould incidence were carried out in the central part of Latvia at the Study and research farm "Peterlauki" of the Latvia University of Agriculture during 2005-2008.

Registration was made on experimental plots designed for investigations of different aspects of winter wheat management. A three-year field study (2005-2007) of winter wheat was conducted at the Study and research farm "Peterlauki" on silt loam brown lessive soil (sod calcareous). Three winter wheat varieties ('Zentos', 'Cubus', and 'Tarso') were sown in four replications on 4 different dates with a 10-day interval from the end of August till the end of September $(30.08 \pm 2,10.09 \pm 2,19.09 \pm 2$, and $29.09 \pm 2)$, and three different seed rates $(300,400$, and 500 seeds per $\mathrm{m}^{2}$ ) were compared. A certified and treated (triticonazol $20 \mathrm{~g} \mathrm{~L}^{-1}$, and prochloraz $60 \mathrm{~g} \mathrm{~L}^{-1}$ ) seed material was used.

During the study years, meteorological conditions in the autumn-winter period differed considerably. The mean 10-day temperature of September was close to the long-term average, but in October 2005 and particularly in October 2006, the mean air temperature of some 10-day periods was 1.5 to 2 times higher than the long-term average. Also in November and December the temperatures were fluctuating. The beginning of November 2005 was very warm. In the first 10-day period the mean air temperature was two times higher $\left(+6^{\circ} \mathrm{C}\right)$ than the long-term average.
Only in the year 2004, temperature in November was close (with insignificant deviations) to the longterm average, and plant vegetation ended later (in the middle of the first ten-day period of November) in comparison with the long-term average (at the end of the last ten-day period of October). However, till the end of the second 10-day period of January, the air temperature was varying between $-4.5{ }^{\circ} \mathrm{C}$ and $+3.5^{\circ} \mathrm{C}$, and only starting from the end of January a stable wintering period set in. The wintering period of 2006/2007 significantly differed from that in the previous years as well as from the longterm average. The growing season continued till mid-December; however, the temperature remained above zero until the third 10-day period of January, and reached its mean value of $+5.0^{\circ} \mathrm{C}$ in the first 10-day period of January. The long autumn vegetation period in 2006, which was comparatively rich in precipitation, had a significant influence on the growth and development of winter wheat, resulting in vigorous tillering and strong overgrowth of the plants sown on the first and also, though partly, on the second sowing date, particularly for winter wheat variety 'Cubus'.

Incidence of snow mould (\% of damaged plants) was determined. The assessment of snow mould was done at the time of starting of wheat vegetation.

Data of snow mould incidence was statistically processed by computer program SPSS 15 . The general linear model was used to evaluate the impact of factors which had influenced the incidence of snow mould. The general linear model included the year of sowing $(\mathrm{i}=1 . .3)$, time of sowing $(\mathrm{i}=1 \ldots 4)$, seed rate $(\mathrm{i}=1 . .3)$, cultivar $(\mathrm{i}=1 . .3)$, and interaction effects between the factors. Pairwise comparisons among factor levels was done using the Bonferroni test; the level of significance was $\alpha=0.05$.

\section{Results}

A rapid development of snow mould, caused by Microdochium nivale, was noticed in Latvia in 20052007 (Fig. 1).

Average incidence of snow mould was $40 \%$ (5-60\%) in $2005,31 \%(14-63 \%)$ in 2006 , and $36 \%$ (2-95\%) in 2007. Different agronomic and ecological factors influenced the development of snow mould. Incidence of snow mould did not differ depending on seed rates, whereas meteorological conditions of year $(\mathrm{p}<0.05)$, cultivar $(\mathrm{p}<0.001)$, and sowing time $(p<0.001)$ significantly affected the disease development (Fig. 1). 


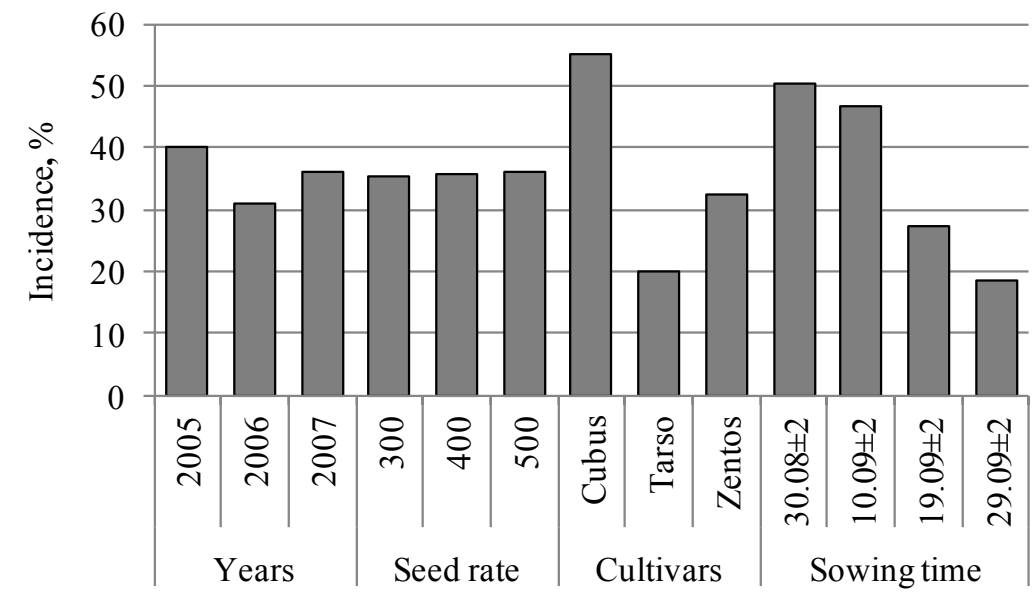

Fig. 1. Development of snow mould depending on different factors.

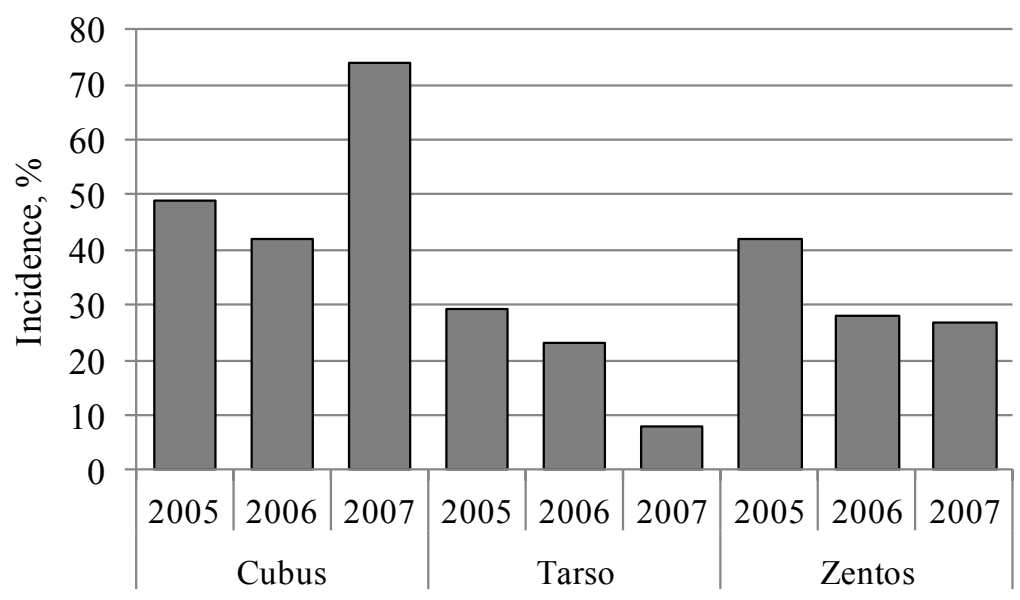

Fig. 2. Development of snow mould depending on cultivars.

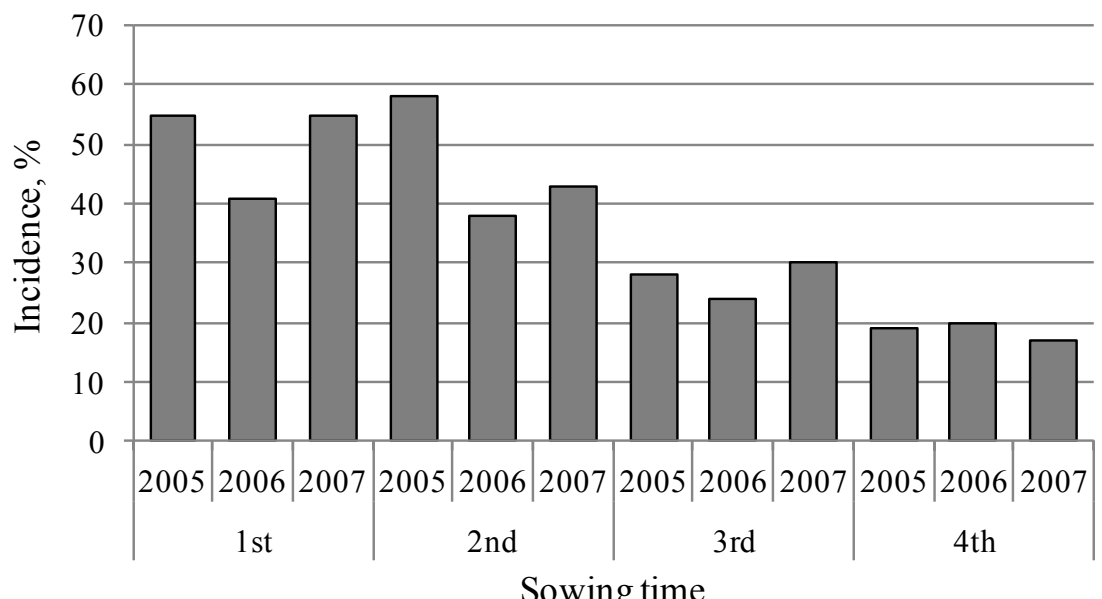

Fig. 3. Development of snow mould depending on the sowing time.

Incidence of snow mould in the year 2005 was significantly higher than in $2006(\mathrm{p}<0.05)$; other differences between the years were not significant.
The cultivar was an important factor $(p<0.05)$, which influenced development of snow mould (Fig. 2). 
The highest incidence of the disease was established for cultivar 'Cubus' - from $23 \%$ to $95 \%$ depending on the year and the sowing time, which on average was $34.9 \%$ higher than for 'Tarso'. A moderate development of snow mould was observed for variety 'Zentos' (5-60\%), but only $2-50 \%$ of damaged plants were found for 'Tarso'.

Sowing time was the most important factor influencing the incidence of snow mould (Fig. 3).

The lowest development of snow mould was observed in plants sown at the latest time of sowing, but the highest - in plants sown at the first sowing time. Average data of disease development differed between the 1 st and 3rd time of sowing (difference - 22.9\%), between $1 \mathrm{st}$ and 4th (difference - 31.8\%), and also between 2nd and 3rd, 2nd and 4th time of sowing (difference accordingly $19.2 \%$ and $28.0 \%$ ).

\section{Discussion}

Snow mould is endemic in general, but outbreaks have been observed in some years, especially if meteorological conditions were favorable for disease development (Matsumoto, 2009). M. nivale and Typhula spp. are causal agents of snow mould under conditions of Latvia, but only $M$. nivale was found during the years of investigations. Infection source of snow mould exists in soil permanently, but development of the disease depends on different factors (Ergon, Skinnes, Tronsmo, 2003). One of the most important reasons for susceptibility against snow mould is high density of sowings, which influences the microclimate and amount of oxygen under the sheet of snow (Bruehl, Cunfer, 1971). However, in our investigations, seed rates did not influence the spread of snow mould - average incidence of snow mould, depending on seed rates, was $36 \%$ each year. It is an unexpected result, because sowing density could determine conditions of overwintering.

Meteorological conditions were favourable for the development of snow mould at the time of investigations. Average incidence of snow mould exceeded $30 \%$. The main factor influencing distribution of snow mould was the high mean ten-day temperature in October, November, also in January of 2005, as well as in December of 2006. The long and warm autumns, and partially winters, promoted overgrowth of wheat. According to findings of other authors, smaller plants survive better (Stupnikova, Borovskii et al., 2002).

Different authors have accented the role of cultivars (Brennan, Leonard et al., 2005). True resistance against $M$. nivale was not found, but infection of causal agents of snow moulds are related with winter hardiness of cultivars. Serenius, Huusela et al. (2005) have observed different levels of pink snow mold depending on rye cultivars, especially when sown at normal sowing time, but in our trials the influence of cultivars was clearly demonstrated in each trial. One of the reasons, which influence resistance against snow mould, is different hardiness of cultivars (Hommo, 1994). 'Cubus' has low hardiness under conditions of Latvia, and in our investigations it proved to be the most susceptible variety against snow mould.

Development of snow mould was influenced by the time of sowing and weather conditions during overwintering. The earlier time of sowing promoted infection with $M$. nivale, which might be related to the development stage of plants and density of sward. Delayed sowing time decreased pink snow mould infection in Finland, where also some exceptions were noted, for example, influence of the location of the trial (Serenius, Huusela et al., 2005). First third of September is traditional time of wheat sowing in the central part of Latvia. Meteorological conditions during the last years have been uncommon for Latvia, autumns have become longer and wormer. Changes in climate is the reason to overestimate traditional management of wheat production.

\section{Conclusions}

Snow mould has become an important disease of winter wheat under conditions of Latvia during the last years. Cultivars and time of sowing are the main factors that influence development of the disease. Further investigations are necessary for better understanding of the complex of factors, which influence wheat susceptibility against snow mould.

\section{References}

1. Brennan, J. M., Leonard, G., Cooke, B. M., \& Doohan, F. M. (2005). Analysis of head and leaf reaction towards Microdochium nivale. European Journal of Plant Pathology, 112, 79-83.

2. Bruehl, G. W., \& Cunfer, B. (1971). Physiologic and environmental factors that affect the severity of snow mold of wheat. Phytopathology, 61, 792-799.

3. Ergon, A., Skinnes, H., \& Tronsmo, A. M. (2003) Testing snow mould resistance of winter wheat: inoculation experiments with Microdochium nivale in the field. Acta Agriculturae 
Scandinavica, Section B - Plant Soil Science, 53, 110-117.

4. Ergon,A., \& Tronsmo, A. M. (2006). Components of pink snow mould resistance in winter wheat are expressed prior to cold hardening and in detached leaves. Journal of Phytopathology, 154(3), 134-142.

5. Gaudet, D. (1994). Progress towards understanding interactions between cold hardiness and snow mould resistance and development of resistant cultivars. Canadian Journal of Plant Pathology, 16, 241-246.

6. Golebiowska, G., \& Wedzony, M. (2009). Cold hardening of winter triticale $(\times$ Triticosecale Wittm.) results in increased resistance to pink snow mould Microdochium nivale (Fr., Samuels\&Hallett) and genotype-dependent chlorophyll fluorescence modulations. Acta Physiology Plant, 31, 1219-1227.

7. Hanslin, H. M., \& Mortensen, L. M. (2010). Autumn growth and cold hardening of winter wheat under simulated climate change. Acta Agriculture Scandinavia, Section B - Plant Soil Science, 60(5), 437-449.

8. Hommo, L. M. (1994). Screening winter rye cultivars for snow mould (Microdochium nivale) resistance. Plant Pathology, 43, 740-750.

9. Kiyomoto, R. K. (1987). Carbon dioxide exchange and total nonstructural carbohydrate in soft white winter wheat cultivars and snow mold resistant introductions. Crop Sciences, 27, 746-752.

10. Litschko, L. D., Burpee, L. L., Goulty, L. G., Hunt, L. A., \& McKersie, B. D. (1988). An evaluation of winter wheat for resistance to the snow mold fungi Microdochium nivale (Fr.) Samu\&Hall and Typhula ishikariensis Imai. Canadian Plant Diseases Survey, 68(2), 161-168.

11. Matsumoto, N. (2009). Snow molds: a group of fungi that prevail under snow. Microbes Environments, 24(1), 14-20.

12. Nakajima, T., \& Abe, J. (1994). Development of resistance to Microdochium nivale in winter wheat during autumn and decline of the resistance under snow. Canadian Journal of Botany, 72(8), 1211-1215.

13. Nazarova, L. N., Korneva, L. G., Sanin, S. S., \& Chen, X. (2008). Diseases of winter and spring wheat in Russia. Journal of Plant Pathology, 90(S2), 166-167.

14. Serenius, M., Huusela-Veistola, E., Avikainen, H., \& Pahkala, K. (2005). Effects of sowing time on pink snow mould, leaf rust and winter damage in winter rye varieties in Finland. Agricultural and Food Science, 14, 362-376.

15. Stupnikova, V., Borovskii, G. B., Dorofeev, N. V., Peshkova, A. A., \& Voinikov, V. K. (2002). Accumulation and disappearance of dehydrins and sugars depending on freezing tolerance of winter wheat plants at different developmental phases. Journal of Thermal Biology, 27(1), 55-60.

16. Sugiyama, S., \& Shimazaki, T. (2007). Increased cell-wall mass and resistance to freezing and snow mold during cold acclimation of winter wheat under field conditions. Plant Production Science, 10(4), 383-390. 